\title{
АНАЛІЗ ОСНОВНИХ ПРАВОВИХ ПОЛОЖЕНЬ ЩОДО ПЕРЕВЕЗЕННЯ ПАСАЖИРІВ ТА БАГАЖУ
}

\begin{abstract}
У статті проаналізовано основні правові положення одного із інститутів транспортного права перевезення пасажирів та багажу, зокрема, нормативно-правову базу перевезень пасажирів різними видами транспорту, окреслено основні напрями іiі систематизації. Дана характеристика правових відносин, які виникають під час перевезення пасажирів різними видами транспорту і які оформлені відповідними цивільними договорами, описані основні права та обов'язки сторін в цих відносинах. Виділені основні підстави юридичної відповідальності за порушення договорів перевезення пасажирів та багажу, а також підняті основні актуальні проблеми, що виникають в діяльності транспортної системи України.

У статті використані різноманітні наукові загальні та спеціальні методи, а саме: логічний, порівняльний, історичний, методи синтезу та аналізу тощо.

Ключові слова: перевезення, пасажири, багаж, транспорт, договір, перевізник, транспортна система, транспортний комплекс.
\end{abstract}

Постановка проблеми. Утворення України та становлення іï як демократичної, правової, соціальної держави стало результатом втілення багатовікових традицій державотворення українського народу. Подальший державний розвиток обумовлює необхідність удосконалення державної політики у сфері перевезень. Транспорт - найважливіша ланка у сфері економічних відносин, одна із провідних галузей матеріального виробництва. Він бере участь у створенні продукції та доставці іiї споживачам, здійснює зв'язок між виробництвом та споживанням, між різними галузями господарства, між країнами та регіонами. Без відносин у сфері перевезення був би неможливий сам процес сучасного виробництва, для якого необхідні зв'язки щодо постачання сировини і продукції.

На сьогоднішній час транспортне право України тільки починас відокремлюватись в самостійну галузь права. У зв'язку з цим в юридичній літературі майже немає робіт, які б висвітлювали основні принципи діяльності та правового регулювання різних видів транспорту.

Аналіз останніх досліджень. Аналізу даної проблеми присвятили свої наукові праці юристи в галузі транспортного, цивільного, господарського права, серед яких можна назвати таких, як Е. Ф. Демський, В. К. Гіжевський, О. В. Дзера, Н. С. Кузнєцова, О. А. Підопригора, Д. В. Боброва, С. М. Приступа, А. П. Сергєєв, Ю. К. Толстой, С. М. Корнєєв, С. Н. Братусь, Ю. А. Попов, В. Ф. Маслов та ін.

Формування цілей роботи. Метою даної роботи $є$ аналіз нормативно-правової бази перевезень пасажирів різними видами транспорту, окреслити основні напрями іiї систематизації.

Основна частина. У всіх країнах світу транспорт $є$ однією 3 важливих галузей народного господарства та складовою частиною міжлюдських стосунків [1]. Сам процес перевезень не виробляє нового продукту, але виступає як сполучна ланка між підприємствами, сприяючи функціонуванню інших галузей економіки, виконанню соціальних завдань, раціональному та гнучкому використанню виробничих сил, забезпечуючи обороноздатність країни.

Тому державна політика становлення та розвитку транспортного комплексу України передбачає забезпечення своєчасного, повного та якісного задоволення потреб населення і суспільного виробництва у перевезеннях, створення рівних умов для розвитку господарської діяльності підприємств транспорту всіх форм власності та входження транспортного комплексу України до європейської і світової транспортної системи [2].

За договором про перевезення пасажира перевізник зобов'язується перевезти пасажира до пункту призначення, а в разі здачі пасажиром багажу - також доставити багаж до пункту призначення i видати його уповноваженій на одержання багажу особі; пасажир зобов'язаний сплатити встановлену плату за проїзд, а при здачі багажу - i за його перевезення [3].

Перевезення пасажирів здійснюється залізничним, річковим, морським, повітряним та автомобільним транспортом, а в містах - метрополітеном, трамваями i тролейбусами. Існують автомобільні приміські, міжміські перевезення пасажирів та міські автобусні, а також перевезення маршрутними та вантажопасажирськими таксомоторами. Перевезення за плату пасажирів та їхніх 
речей громадянами, які здійснюють їх епізодично, регулюються нормами про договір підряду, а не правилами транспортного законодавства.

Роль і значення транспорту закріплено статтею 1 Закону України «Про транспорт» [4], в якій визначається, що транспорт $є$ однією 3 найважливіших галузей суспільного виробництва, яка покликана задовольнити потреби населення та суспільного виробництва в перевезеннях. Отже, законодавець визначає транспорт як важливу галузь суспільного виробництва, що перебуває у тісній взаємодії 3 промисловістю, енергетичним, агропромисловим, будівельним і торговельним комплексом, зв'язком, житловим господарством, побутовим обслуговуванням населення, сферою використання й охорони природних ресурсів тощо. У кожній з перерахованих галузей є окремі специфічні матеріальні умови виробництва, технологічні процеси, структура підприємств, особовий склад працівників тощо.

На теперішній час чи не найпоширеніша функція транспорту полягає у перевезенні пасажирів. Щорічно обсяги перевезення пасажирів збільшуються на таких видах транспорту, як автомобільний, залізничний, відновлює свої можливості за рахунок покращення матеріальної та технічної бази річковий, морський та авіаційний транспорт.

На даний час вважається, що для задоволення потреб у перевезенні пасажирів та багажу необхідні транспортні засоби й комплекси, які мають бути побудовані й повинні перебувати у відповідному технічному стані, своєчасне впровадження заходів технічного переозброєння i передових методів 3 вдосконалення всіх ланок транспортної системи. Досягнення стратегічних результатів, які повинна забезпечувати транспортна система, залежить від виконання вищезазначених завдань.

На теперішній час в Україні транспортний комплекс має свою організаційну структуру. За Законом України «Про транспорт» (ст. 21) у нашій країні сформована Єдина транспортна система, яка охоплює всі види державного, колективного й приватного транспорту, транспортно-технічні засоби, рухомий склад, структури управління на кожному виді транспорту та соціально-економічного забезпечення. Підтвердженням цьому є статті 22-40 зазначеного вище Закону.

Необхідно зазначити, що в юридичній літературі вважається, що транспортні правовідносини мають всі ознаки цивільно-правових відносин, які врегульовані нормами цивільного права на підставах договору перевезень.

Враховуючи формування нових економічних відносин, створення стабільної та незалежної ринкової інфраструктури на сьогоднішній день повинні бути актуальними питання подальшого розвитку транспортної системи, збільшення обсягів перевезень, в тому числі і пасажирів, що забезпечить наповнюваність державного та місцевих бюджетів.

Зміст спеціальної правоздатності деяких підприємств становить виробнича діяльність з надання послуг. Одні послуги являють собою результат певних видів діяльності або праці (споживні вартості) і втілюються у товарах, інші, навпаки, не залишають реальних результатів, які б існували окремо від виконавців цих послуг. Головною особливістю договорів про надання послуг, на відміну від договорів про виконання робіт, $є$ те, що надання послуг невіддільне від діяльності особи, яка надає послуги. Корисний ефект такої діяльності не виступає у вигляді певного збагненого матеріалізованого результату, як це має місце у підрядних договорах, а полягає в самому процесі надання послуги. Зобов’язання з надання послуг виникають, зокрема, з транспортних договорів.

У ст. 6 Закону України «Про транспорт» визначено загальні основи господарської діяльності підприємств транспорту. Перевезення пасажирів, вантажів, багажу та пошти, надання інших транспортних послуг, експлуатація та ремонт шляхів здійснюють залізниці, пароплавства, порти (пристані), автомобільні, авіаційні, дорожні підприємства, якщо це передбачено їх статутами.

Підприємства транспорту здійснюють перевезення та надають послуги на основі державних контрактів і договорів про перевезення пасажирів і вантажів з урахуванням економічної ефективності перевізних та переробних можливостей транспорту. Економічні відносини підприємств транспорту, що виникають у процесі перевезення, грунтуються на принципах взаємної вигоди, рівної та повної відповідальності [5].

Відносини підприємств транспорту загального користування з центральними та місцевими органами виконавчої влади та органами місцевого самоврядування будуються на основі податків, податкових пільг, встановлених нормативів та інших економічних засобів відповідно до чинного законодавства України.

Транспортні договори поділяються на основні та допоміжні. Основні транспортні договори опосереднюють головну сферу взаємовідносин транспортних організацій та клієнтури (договори про перевезення пасажирів, вантажів, багажу та пошти, договори буксирування). Допоміжні договори 
сприяють нормальній організації перевізного процесу (договори на організацію перевезень, експедиції, на експлуатацію під'їзних колій, подачу і забирання вагонів тощо).

Перевезення пасажирів, вантажів, багажу та пошти залежно від видів транспорту, якими вони здійснюються, поділяються на: а) залізничні; б) внутрішніми водними шляхами (річкові); в) морські; г) повітряні; д) автомобільні.

Крім того, перевезення у межах територіальної сфери дії однієї транспортної організації (наприклад, Львівської залізниці) вважаються перевезеннями місцевого сполучення; перевезення двома чи кількома організаціями одного виду транспорту є перевезеннями у прямому сполученні, а перевезення за єдиним транспортним документом організаціями різних видів транспорту перевезеннями у прямому змішаному сполученні. На морському транспорті перевезення та буксирування бувають: а) каботажні - між портами України; б) міжнародні - між іноземними портами [6].

Розгорнені правила, які регулюють відносини щодо перевезення пасажирів, багажу i вантажобагажу залізничним транспортом, встановлені Порядком обслуговування громадян залізничним транспортом, Правилами перевезень пасажирів, багажу, вантажобагажу та пошти залізничним транспортом України. Укладення договорів перевезення пасажира автомобільним транспортом має свою специфіку. Зазвичай такі договори укладаються автовокзалами, автостанціями, від імені перевізника (ст. 42 Закону України «Про автомобільний транспорт»). Договір укладається в письмовій формі, якщо може бути пасажирський квиток, договір, квитанція тощо. Встановлюється, що договір вважається укладеним з моменту придбання пасажиром квитка на право проїзду. Укладений в такий спосіб договір набуває чинності з моменту посадки пасажира в автомобільний транспортний засіб. При туристичних перевезеннях, при перевезеннях на замовлення, а також у випадках, коли пасажир користується правом пільгового проїзду, договір перевезення вважається укладеним 3 моменту посадки в автобус. Щодо таксі встановлюється, що 3 моменту посадки пасажира договір перевезення набуває чинності (ст. 52 Закону України «Про автомобільний транспорт»). Всі ці особливості визначення моменту укладення договору перевезення та набуття ним чинності не мають істотного практичного значення, а лише підкреслюють неконструктивність ідеї використання поряд 3 правовою конструкцією укладення цивільно-правового договору правової конструкції набуття (набрання) ним чинності відповідно до ст. 631 Цивільного кодексу України (далі -ЦК).

Кожен із видів транспорту є окремою господарською системою, що взаємодіє 3 іншими транспортними системами. Крім перелічених, існує ще один вид транспорту - трубопровідний, який перекачує нафту, газ, воду тощо. Проте відносини, що складаються при транспортуванні цих продуктів трубопроводами, регулюються або законодавством про поставки, або законодавством про постачання енергетичних та інших ресурсів через приєднану мережу. Організація, що експлуатує трубопровід, водночас $є$ й володільцем продукції, яка перебуває у трубопроводі [7].

Згідно зі статутами (кодексами) розробляються та затверджуються правила перевезення на окремих видах транспорту, а також у змішаному сполученні.

Різновидом договору перевезення $є$ договір перевезення пасажира та багажу, за яким одна сторона (перевізник) зобов'язується перевезти другу сторону (пасажира) до пункту призначення, а в разі здавання багажу - також доставити багаж до пункту призначення та видати його особі, яка має право на одержання багажу, а пасажир зобов'язується сплатити встановлену плату за проїзд, а у разі здавання багажу - також за його провезення [3].

Сторонами договору є пасажир - фізична особа (як при перевезенні пасажира, так і його багажу) та перевізник (транспортна організація, яка належить, як правило, до транспорту загального користування).

Щодо форми договору, то слід зауважити, що допускається усна (при купівлі квитка або шляхом здійснення конклюдентних дій, наприклад, шляхом подання міського транспорту до зупинки, посадка пасажира в таксі, прохід через турнікети метро, сплата за проїзд жетоном тощо).

Предметом договору є надання послуг, пов'язаних із перевезенням.

Щодо договору перевезення пасажира, то не допускається будь-яка домовленість між перевізником і пасажирами про обмеження або виключення встановленої законом відповідальності перевізника. Однак таке правило не виключає можливості домовленості про обмеження або виключення передбаченої відповідальності пасажира, а також про підвищення відповідальності перевізника, наприклад, у разі повітряного перевезення.

Відповідно до ст. 922 ЦК за затримку у відправленні транспортного засобу, що перевозить пасажира, або запізнення у прибутті такого транспортного засобу до пункту призначення перевізник 
сплачує пасажирові штраф у розмірі, встановленому за домовленістю сторін транспортними кодексами (статутами). Перевізник звільняється від відповідальності, якщо це сталося внаслідок: непереборної сили; усунення несправності транспортного засобу, яка загрожувала життю або здоров'ю пасажира; інших обставин, що не залежали від перевізника.

Характерною рисою відповідальності за невиконання або неналежне виконання зобов’язань за договором перевезення багажу є іiі обмежений характер. Наприклад, відповідно до ст. 68 Закону України «Про автомобільний транспорт» [8] у разі втрати або нестачі багажу - в розмірі вартості багажу, який втрачено або якого бракує; у разі пошкодження (псування) багажу - в розмірі суми, на яку зменшилася вартість багажу; у разі втрати багажу, зданого для перевезення з оголошенням його цінності, - в розмірі оголошеної цінності багажу.

Згідно зі ст. 928 ЦК перевізник несе відповідальність за шкоду, завдану каліцтвом, іншим ушкодженням здоров'я або смертю пасажира за правилами глави 82 ЦК, якщо договором або законом не встановлено відповідальність перевізника без вини. Можливість притягнення перевізника до цивільно-правової відповідальності за шкоду, завдану каліцтвом, іншим ушкодженням здоров'я або смертю пасажира зумовлено тією обставиною, що законодавець розглядає транспортний засіб як джерело підвищеної небезпеки (ст. 1187 ЦК). А особа, яка здійснює діяльність, що є джерелом підвищеної небезпеки, відповідає також за завдану шкоду, якщо вона не доведе, що шкоди було завдано внаслідок непереборної сили або умислу потерпілого.

В ст. 924 ЦК передбачено, що перевізник звільняється від відповідальності за втрату, нестачу, псування або пошкодження прийнятого до перевезення вантажу, багажу, пошти, якщо доведе відсутність своє вини.

Обставини, які звільняють перевізника від відповідальності, зазначені у відповідних транспортних кодексах і статутах.

Слід відмітити, що перевізник звільняється від відповідальності за недостачу, пошкодження та псування вантажу у випадках, якщо: вантаж прибув у справному транспортному засобі 3 непорушеними пломбами відправника; вантаж супроводжував експедитор чи представник вантажовідправника чи вантажоодержувача; недостача вантажу не перевищує норм природних втрат; недостача вантажу не перевищує допустимого розходження при визначенні його маси (наприклад, якщо вагон із зерном зважують на вагонних вагах); вологість вантажу перевищувала допустиму норму (на окремі види вантажу встановлена норма вологості - цукор, вугілля, сіль, борошно тощо); вантаж зіпсувався, оскільки відправник завантажив вантаж у непідготовлений, неочищений транспортний засіб, який сам же і розвантажував; вантаж був зданий до перевезення без зазначення його особливостей, які вимагали особливих вимог перевезення («з гірки не спускати»); швидкопсувний вантаж зіпсувався, але перевізник дотримувався режиму перевезення, а строк перевезення не перевищив допустимого та ін.

Висновки. У роботі доведено, що на теперішній час основним завданням транспорту залишається задоволення потреб населення у перевезеннях. Основні функції, які сьогодні виконує транспорт, пов'язані саме із перевезенням пасажирів та багажу.

Значна роль при перевезенні пасажирів та багажу відводиться державі, основними завданнями якої є формування ринку транспортних послуг шляхом реалізації єдиної економічної, інвестиційної, науково-технічної та соціальної політики.

1. Киричок А. Роль транспортной отрасли в устойчивом развитии экономики Украины / А. Киричок, Н. Швец //.Международный журнал «Устойчивое развитие». - 2014. - № 15, февраль. Варна. - С. 69-74.

2. Кірічок О. Г. Проблеми та перспективи розвитку транспортної системи України в умовах ії інтеграції в транспортні структури Європи / О. Г. Кірічок: Збірник тез VI Міжнародної науково-практичної конференції «Проблеми i механізми відтворення ресурсного потенціалу України в контексті євроінтеграції», 16-17 жовтня 2014 р., м. Рівне. - Рівне: НУВГП, 2014. - С. 62-65.

3. Цивільний кодекс України. № 435-IV від 16.01.2003 // Відомості Верховної Ради України, 2003, №№ 40-44.

4. Закон України «Про транспорт» від 10.11.1994 // Відомості Верховної Ради України, 2001, № 9.

5. Осоченко І. В. Транспортне співробітництво як ефективний засіб регулювання зовнішньоекономічної діяльності в регіоні / І. В. Осоченко. - № 1 (8). - 2000. - С. 64-66.

6. Яцківський Л. Ю. Загальний курс транспорту / Л. Ю. Яцківський, Д. В. Зеркалов: Навч. посіб. Кн. 1, 2. - К. : Арістей, 2007, 2009.

7. Цивільне право: Особлива частина / за ред. проф. О. А. Підопригори і Д. В. Бобрової. - К.: Вентурі, $2004 .-540$ с.

8. Закон України «Про автомобільний транспорт» від 5.042001 // Відомості Верховної Ради України, 2001, № 22. 


\section{REFERENCES}

1. Kirichok, A., Shvets, N. (2014). Rol transportnoi otrasli v ustoichivom razvitii ekonomiki Ukrainy [The role of the transport industry in the sustainable development of the Ukrainian economy] / International Journal "Sustainable Development", 15, February, Varna, Euro-Expert EOOD Pb., TU - Varna, 69-74.

2. Kirichok O.G. (2014). Problemy ta perspektyvy rozvytku transportnoi systemy Ukrainy v umovakh yii intehratsii v transportni struktury Yevropy [Problems and possibilities of the transport system development in Ukraine in conditions of its integration into the transport structures of Europe]. A collection of theses of the VI International scientific and practical conference "Problems and mechanisms of reproduction of Ukraine's resource potential in the context of European integration", Rivne, NUWEE, $62-65$.

3. Tsyvilnyi kodeks Ukrainy [The Civil Code of Ukraine]. 435-IV nr. of January 16, 2003. Bulletin of the Information from the Verkhovna Rada of Ukraine, 2003, 40-44 nr.

4. Zakon Ukrainy "Pro transport" [The Law of Ukraine "About transport"] of 10.11.1994. Information from the Information from the Verkhovna Rada of Ukraine, 2001, $9 \mathrm{nr}$.

5. Osochenko, I.V. (2000). Transportne spivrobitnytstvo yak efektyvnyi zasib reguliuvannia zovnishnoekonomichnoi diyalnosti $v$ regioni.[Transport cooperation as an effective means of foreign economic activity regulation in the region]. Regional perspectives, 1 (8), 2000, 64-66.

6. Yatskivski, L.Y., Zerkalov, D.V. (2007, 2009). Zagalnyi kurs transportu [General course of transport: teaching. manual]. Kyiv. Aristey $\mathrm{Pb}$. $\mathrm{Pb} ., 2004$

7. Tsyvilne pravo: osoblyva chastyna [Civil law: special part], ed. prof. Pidopygory O.A. and Bobrovoi D.B., Kyiv, Venturi

8. Zakon Ukrainy "Pro avtomobilnyi transport" [The Law of Ukraine "About Road Transport"] dated April 5, 2001, Bulletin of the Verkhovna Rada of Ukraine, 22 nr., Kyiv.

Киричок А. Г., Антонюк В. П., Шевченко О. В. Анализ основных правовых положений относительно перевозок пассажиров и багажа.

В статье проанализированы основные правовые положения одного из институтов транспортного права - перевозки пассажиров и багажа, в частности, нормативно-правовую базу перевозок пассажиров различными видами транспорта, определены основные направления её систематизации. Дана характеристика правовых отношений, возникающих при перевозке пассажиров различными видами транспорта и оформленных соответствующими гражданскими договорами, описаны основные права и обязанности сторон в этих отношениях. Выделены основные основания юридической ответственности за нарушение договоров перевозки пассажиров и багажа, а также подняты основные актуальные проблемы, возникающие в деятельности транспортной системы Украины.

В статье использованы различные научные общие и специальные методы, а именно: логический, сравнительный, исторический, методы синтеза и анализа и др.

Ключевые слова: перевозки, пассажиры, багаж, транспорт, договор, перевозчик, транспортная система, транспортный комплекс.

O. Kirichok, V. Antoniuk, O. Shevchenko. The analysis of the main legal positions on the passengers and baggage transportation.

The main legal provisions of the institutes of transport law - the transport of passengers and baggage are analyzed in the article. The regulatory framework for the transport of passengers by various types of transport is decomposed. The main directions of its systematization are proposed. The characteristic of the legal relations arising during the transportation of passengers by various types of transport and executed by the relevant civil contracts are given. The basic rights and obligations of the parties in these relations are described. The main grounds for legal liability for violation of contracts for the carriage of passengers and baggage are highlighted. The main urgent problems arising in the activities of the transport system of Ukraine are raised.

The article uses various scientific general and special methods, in particular: logical, comparative, historical, methods of synthesis and analysis, etc.

Key words: transportation, passengers, baggage, transport, contract, carrier, transport system, transport complex.

КІРІЧОК Олександр Георгійович, кандидат технічних наук, доцент кафедри транспортних технологій і технічного сервісу, Національний університет водного господарства та природокористування, e-mail: o.h.kirichok@nuwm.edu.ua

АНТОНЮК Валентина Петрівна, виконувач обов'язків директора, Рівненський автотранспортний коледж Національного університету водного господарства та природокористування, e-mail: ratk@nuwm.edu.ua

ШЕВЧЕНКО Оксана Володимирівна, завідувач відділення «Транспортні технології», Рівненський автотранспортний коледж Національного університету водного господарства та природокористування, e-mail: ratk@nuwm.edu.ua

КИРИЧОК Александр Георгиевич, кандидат технических наук, доцент кафедры транспортных технологий и технического сервиса, Национальный университет водного хозяйства и природопользования, e-mail: o.h.kirichok@ nuwm.edu.ua

АНТОНЮК Валентина Петровна, исполняющая обязанности директора, Ровенский автотранспортный колледж Национального университета водного хозяйства и природопользования, e-mail: ratk@nuwm.edu.ua 
ШЕВЧЕНКО Оксана Владимировна, заведующая отделением «Транспортные технологии», Ровенский автотранспортный колледж Национального университета водного хозяйства и природопользования, e-mail: ratk@nuwm.edu.ua

Oleksandr KIRICHOK, PhD in Engineering, Assoc. Professor of Transport Technology and Service Department, National University of Water and Environmental Engineering, e-mail: o.h.kirichok@nuwm.edu.ua

Valentina ANTONIUK, Acting Director, Rivne Motor Transport College of the National University of Water and Environmental Engineering, e-mail: ratk@nuwm.edu.ua

Oksana SHEVCHENKO, Head of the Transport Technologies Department, Rivne Motor Transport College of the National University of Water and Environmental Engineering, e-mail: ratk@ nuwm.edu 